\title{
Anxiety and depression as possible criteria in the treatment of bronchiectasis
}

\author{
Bronşektazi tedavisinde ölçüt olarak anksiyete ve depresyon \\ Hakan Keskin' ${ }^{(0,}$, Hülya Dirol ${ }^{2}\left[\right.$, Makbule Ergin' ${ }^{(1)}$ \\ 'Department of Thoracic Surgery, Akdeniz University Faculty of Medicine, Antalya, Turkey \\ ${ }^{2}$ Department of Chest Diseases, Akdeniz University Faculty of Medicine, Antalya, Turkey
}

\begin{abstract}
Background: The aim of this study was to investigate the effect of bronchiectasis operation on anxiety and depression.

Methods: Between August 2014 and March 2019, a total of 167 patients with bronchiectasis (107 males, 60 females; mean age: $43.5 \pm 13.9$ years; range, 18 to 84 years) who received medical $(n=70)$ and surgical $(n=97)$ treatment were retrospectively analyzed. Data including patients' characteristics, operation indication, operation type, and bronchiectasis localization were obtained from the electronic patient files. The patients were reached via phone calls and evaluated whether the operation provided a significant symptomatic improvement and whether the symptoms disappeared. The number of exacerbations/hospitalizations associated with bronchiectasis within the last year was also questioned. The anxiety and depression status of the patients in both groups was assessed by the Hospital Anxiety and Depression Scale.
\end{abstract}

Results: Eleven (15\%) patients in the medical group and $10(10 \%)$ patients in the surgical group had an anxiety score above 7. Twenty-one $(30 \%)$ patients in the medical group and $10(10 \%)$ patients in the surgical group had a depression score above 7. Both the anxiety and depression scores were significantly lower in the surgical group than the medical group $(\mathrm{p}<0.001)$. Annual exacerbation and annual hospitalization rates were also significantly lower in the surgical group $(\mathrm{p}<0.001)$.

Conclusion: Our study results suggest that patients with bronchiectasis treated medically rather than surgically are more prone to be anxious and depressive. The benefits of surgical treatment in patients with bronchiectasis is not limited to improving symptoms and decreasing the frequency of exacerbations/hospitalizations. We believe that surgical treatment also reduces anxiety and depression and improve the quality of life. While making a surgical decision, the anxiety/depression status of bronchiectasis patients should be considered.

Keywords: Anxiety, bronchiectasis, depression, hospitalization, surgery.
$\ddot{O Z Z}$

Amaç: $\mathrm{Bu}$ çalışmada, bronşektazi cerrahisinin anksiyete ve depresyon üzerindeki etkisi araştırıldı.

Çalışma planı: Ağustos 2014-Mart 2019 tarihleri arasında medikal $(n=70)$ ve cerrahi $(n=97)$ tedavi uygulanan toplam 167 bronşektazi hastası (107 erkek, 60 kadın; ort. yaş: $43.5 \pm 13.9$ yıl; dağ $\breve{l l}_{1}$, 18-84 y1l) retrospektif olarak incelendi. Hastaların özellikleri, cerrahi endikasyonu, cerrahi türü ve bronşektazi lokalizasyonu dahil olmak üzere veriler elektronik hasta dosyalarından elde edildi. Hastalara telefon ile ulaşılarak, ameliyatın önemli bir semptomatik iyileşme sağlayıp sağlamadığ ve semptomların kaybolup kaybolmadığı değerlendirildi. Son bir yıl içinde bronşektaziye bağlı alevlenme/hastane yatış sayısı da sorgulandı. Her iki grupta da hastaların anksiyete ve depresyon durumu, Hastane Anksiyete ve Depresyon Ölçeği ile değerlendirildi.

Bulgular: Medikal grupta 11 (\%15) hastanın ve cerrahi grupta $10(\% 10)$ hastanın anksiyete skoru $>7$ idi. Medikal grupta $21(\% 30)$ hastanın ve cerrahi grupta $10(\% 10)$ hastanın depresyon skoru $>7$ idi. Hem anksiyete hem de depresyon skorları, medikal gruba kıyasla, cerrahi grupta anlamlı olarak daha düşük idi $(\mathrm{p}<0.001)$. Yıllık alevlenme ve yıllık hastaneye yatış oranları da, cerrahi grupta anlamlı olarak daha düşük idi $(\mathrm{p}<0.001)$.

Sonuç: Çalışma sonuçlarımız, cerrahiye kıyasla medikal olarak tedavi edilen bronşektazi hastalarının daha kaygılı ve depresif olma eğiliminde olduğunu göstermektedir. Bronşektazili hastalarda cerrahi tedavinin faydaları, semptomların iyileştirilmesi ve alevlenme/hastaneye yatış sıklı̆̆ının azaltılması ile sınırlı değildir. Cerrahi tedavinin anksiyete ve depresyonu da azalttı̆̆ ve yaşam kalitesini artırdığı kanısındayız. Cerrahi karar alınırken, bronşektazili hastaların anksiyete/depresyon durumu da göz önünde bulundurulmalıdır.

Anahtar sözcükler: Anksiyete, bronşektazi, depresyon, hastaneye yatış, cerrahi.

Received: June 24, 2020 Accepted: September 18, 2020 Published online: April 26, 2021

Correspondence: Hakan Keskin, MD. Akdeniz Üniversitesi Tıp Fakültesi Göğüs Cerrahisi Anabilim Dalı, 07070 Konyaaltı, Antalya, Türkiye.

Tel: +90 505 - 7966997 e-mail: opdrhakankeskin@hotmail.com.tr 
Bronchiectasis is a chronic airway disease characterized by dilated thick-walled bronchi and bronchioles as a result of chronic airway inflammation and disturbed mucociliary clearance. ${ }^{[1]}$ Patients with bronchiectasis are at an increased risk for anxiety and depression. ${ }^{[2]}$ The frequency of anxiety and depression as assessed by Hospital Anxiety and Depression Scale (HADS) is very high, reaching up to one-third of the patients with bronchiectasis. ${ }^{[2]}$ Presumably, physical symptoms and social isolation play a role in this mood disorder that further reduces the patient's ability to fight against the disease.

Although anxiety and depression are common in patients with bronchiectasis and the presence of both conditions is significantly associated with worsened respiratory symptoms, as well as the increased health expenditure and non-compliance to therapy, this situation attracts little attention in decision for surgical treatment of bronchiectasis. Anxiety and depression, which are related to frequent exacerbations, hemoptysis, and intense sputum production, is ignored by surgeons, while all these related risk factors are considered operation indications.

In the present study, we aimed to compare the operated patients with the non-operated ones in respect to anxiety/depression and to evaluate whether the operation was beneficial from the perspective of patients, considering the eradication of symptoms, exacerbations, and hospitalizations related to bronchiectasis.

\section{PATIENTS AND METHODS}

This single-center, retrospective, cross-sectional study was conducted at Akdeniz University, Faculty of Medicine, Department of Thoracic Surgery and Chest Diseases between August 2014 and March 2019. A list of patients with the International Classification of Diseases-10 (ICD-10) code J47 "bronchiectasis" was obtained from the hospital electronic patient registration system, namely MIA-MED. Among a total of 344 patients, 167 (107 males, 60 females; mean age: $43.5 \pm 13.9$ years; range, 18 to 84 years) were included in the study. Of these, 97 who underwent surgical treatment for bronchiectasis and 70 patients who refused bronchiectasis operation and treated medically were included in the study. Patients who underwent bronchiectasis operation constituted the surgical group, and the patients who refused the operation and received medical treatment constituted the medical group. Patients aged $<18$ years old, those with another major comorbidity, those who were unable to be reached via phone calls, and those who were unwilling to answer questions were excluded. A written informed consent was obtained from each patient. The study protocol was approved by the Ethics Committee of Akdeniz University, School of Medicine (Date: 23.01.2020 No: 70904504/25). The study was conducted in accordance with the principles of the Declaration of Helsinki.

Surgical indications for bronchiectasis were as follows: (i) frequent pulmonary infections, (ii) no exercise dyspnea, (iii) hemoptysis, (iv) destroyed lobes, and $(v)$ chronic cough and sputum production that was unresponsive to medical treatment. Patients with adequate pulmonary and cardiac reserves and regional involvement were considered eligible for surgery. During bronchiectasis operations in our hospital, it is required to have a forced expiratory volume in one second $\left(\mathrm{FEV}_{1}\right)$ value of at least 1.5 liters for lobectomy and $\geq 2$ liters for pneumonectomy. Preoperative treatments such as antibiotic therapy based on sputum culture results, mucolytic agent, bronchodilator, and respiratory exercises for 15 days were applied to all patients with purulent sputum. Each patient underwent bronchoscopy for intrabronchial foreign body examination before the operation. All patients were operated by a single anesthesia and surgical team. Double-lumen endotracheal intubation tube was used in all patients. All patients were operated with a posterolateral thoracotomy incision. After pulmonary resection, the bronchial stump was sutured with non-absorbable sutures. The bronchial stump strengthening is not a routine procedure in our clinic.

Data including patients' characteristics, operation indication, operation type, and bronchiectasis localization were collected from the electronic files of the patients.

Both patient groups were reached via phone calls at February 2020. The operated patients were asked questions about whether the operation provided a significant symptomatic improvement and whether the symptoms disappeared. All patients were asked how many bronchiectasis-related exacerbation/hospitalization they had within the previous year. Via phone calls, the HADS was used to evaluate anxiety and depression status of the patients in both groups. The HADS questionnaire is composed of a total of 14 questions, seven for depression and seven for anxiety, each of which is scored on a scale from 0 to 3 . In validation of this questionnaire, a score of $>7$ for both subscales indicates anxiety and depression. The validity and reliability studies of the HADS were conducted in the Turkish population in 1997 (Table 1). ${ }^{[3]}$ 


\section{Statistical analysis}

Statistical analysis was performed using the IBM SPSS version 21.0 software (IBM Corp., Armonk, NY, USA). was used for the analysis. Descriptive statistics were presented in mean \pm standard deviation (SD), median (min-max) or number and frequency, where applicable. The Fisher's exact test or Pearson chi-square test was used to analyze the relationship between categorical variables. For the distribution of numerical variables, the Kolmogorov-Smirnov test was used. The Student's t-test, Mann-Whitney U test, analysis of variance one-way ANOVA, and Sidak test

Table 1. Hospital Anxiety and Depression Scale (HADS) questionnaire

\begin{tabular}{|c|c|c|c|}
\hline \multicolumn{2}{|r|}{ Anxiety } & \multicolumn{2}{|r|}{ Depression } \\
\hline & I feel tense or 'wound up': & & I feel as if I am slowed down: \\
\hline 3 & Most of the time & 3 & Nearly all the time \\
\hline 2 & A lot of the time & 2 & Very often \\
\hline 1 & From time to time, occasionally & 1 & Sometimes \\
\hline 0 & Not at all & 0 & Not at all \\
\hline & $\begin{array}{l}\text { I get a sort of frightened feeling like 'butterflies' } \\
\text { in the stomach: }\end{array}$ & & I still enjoy the things I used to enjoy: \\
\hline 3 & Very often & 3 & Hardly at all \\
\hline 2 & Quite often & 2 & Only a little \\
\hline 1 & Occasionally & 1 & Not quite so much \\
\hline 0 & Not at all & 0 & Definitely as much \\
\hline & $\begin{array}{l}\text { I get a sort of frightened feeling as if something } \\
\text { awful is about to happen: }\end{array}$ & & I have lost interest in my appearance: \\
\hline 3 & Very definitely and quite badly & 3 & Definitely \\
\hline 2 & Yes, but not too badly & 2 & I don't take as much care as I should \\
\hline 1 & A little, but it doesn't worry me & 1 & I may not take quite as much care \\
\hline 0 & Not at all & 0 & I take just as much care as ever \\
\hline & I feel restless as I have to be on the move: & & I can laugh and see the funny side of things: \\
\hline 3 & Very much indeed & 3 & Not at all \\
\hline 2 & Quite a lot & 2 & Definitely not so much now \\
\hline 1 & Not very much & 1 & Not quite so much now \\
\hline 0 & Not at all & 0 & As much as I always could \\
\hline & Worrying thoughts go through my mind: & & I look forward with enjoyment to things: \\
\hline 3 & A great deal of the time & 3 & Hardly at all \\
\hline 2 & A lot of the time & 2 & Definitely less than I used to \\
\hline 1 & From time to time, but not too often & 1 & Rather less than I used to \\
\hline 0 & Only occasionally & 0 & As much as I ever did \\
\hline & I get sudden feelings of panic: & & I feel cheerful: \\
\hline 3 & Very often indeed & 3 & Not at all \\
\hline 2 & Quite often & 2 & Not often \\
\hline 1 & Not very often & 1 & Sometimes \\
\hline 0 & Not at all & 0 & Most of the time \\
\hline & I can sit at ease and feel relaxed: & & I can enjoy a good book or radio or $\mathrm{TV}$ program: \\
\hline 3 & Not at all & 3 & Very seldom \\
\hline 2 & Not Often & 2 & Not often \\
\hline 1 & Usually & 1 & Sometimes \\
\hline 0 & Definitely & 0 & Often \\
\hline
\end{tabular}


were used to compare the groups. A $p$ value of $<0.05$ was considered statistically significant.

\section{RESULTS}

There was no significant difference in the sex between the groups $(p=0.48)$. However, the surgical group was significantly older than the medical group $(\mathrm{p}<0.001)$.

Eleven (15\%) patients in the medical group and $10(10 \%)$ patients in the surgical group had an anxiety score above 7 . Twenty-one (30\%) patients in the medical group and $10(10 \%)$ patients in the surgical group had a depression score above 7 . The mean HADS anxiety and depression scores were $4.9 \pm 1.5$ and $3.1 \pm 1.4$ in the surgical group, respectively. The mean HADS anxiety and depression scores were $5.9 \pm 2.5$ and $5.5 \pm 2.4$ in the medical group, respectively. Both the HADS anxiety and depression scores were significantly lower in the surgical group than the medical group $(\mathrm{p}<0.001)$.

In $55(56.7 \%)$ patients in the surgical group, the operation indication for bronchiectasis was expectoration and social problem related to sputum. The second most common indication for surgery was frequent exacerbation, followed by hemoptysis. Operation of the left lower lobe bronchiectasis was

Table 2. Demographic and clinical characteristics of study population

\begin{tabular}{lccc}
\hline & Mean \pm SD & Min-Max & $p$ \\
\hline Age & & & \\
Medical Group & $37.2 \pm 10.4$ & $18-84$ & 0.001 \\
$\quad$ Surgical Group & $48.0 \pm 14.4$ & $19-84$ & \\
Annual exacerbation & & & \\
$\quad$ Medical Group & $1.5 \pm 1.2$ & $0-5$ & 0.001 \\
$\quad$ Surgical Group & $0.6 \pm 0.4$ & $0-2$ & \\
Annual hospitalization & & & \\
$\quad$ Medical Group & $1.1 \pm 0.5$ & $0-6$ & 0.079 \\
$\quad$ Surgical Group & $0.4 \pm 0.2$ & $0-2$ & \\
HADS anxiety & & & \\
$\quad$ Medical Group & $5.9 \pm 2.5$ & $0-16$ & 0.001 \\
$\quad$ Surgical Group & $4.9 \pm 1.5$ & $0-14$ & \\
HADS depression & & & \\
$\quad$ Medical Group & $5.5 \pm 2.4$ & $0-11$ & 0.001 \\
$\quad$ Surgical Group & $3.1 \pm 1.4$ & $0-10$ & \\
\hline
\end{tabular}

SD: Standard deviation; Min: Minimum; Max: Maximum; HADS: Hospital Anxiety and Depression Scale. performed most frequently in $44(45.4 \%)$ patients. One (1\%) patient had pneumectomy, $68(70.1 \%)$ patients had lobectomy, $15(15.4 \%)$ patients had segmentectomy, and $13(13.4 \%)$ patients had wedge resection.

To the question of whether the operation provided a significant symptomatic improvement, 72 (74.2\%) patients responded as "Yes, it did". The symptoms disappeared in $70(72.2 \%)$ patients, while symptoms remained unchanged in $19(19.6 \%)$ patients and eight $(8.2 \%)$ patients experienced progression of the symptoms. The mean annual exacerbation number was $0.6 \pm 0.4$ in the surgical group and $1.5 \pm 1.2$ in the medical group, indicating a significantly lower number in the surgical group than the medical group $(\mathrm{p}<0.001)$. The mean annual hospitalization was $0.4 \pm 0.2$ in the surgical group and $1.1 \pm 0.5$ in the medical group, indicating no statistically significant difference between the groups $(\mathrm{p}=0.079)$ (Table 2).

\section{DISCUSSION}

In the present study, we observed that medically treated patients were more anxious and depressive than the operated patients. In addition, this study showed once again that surgical treatment provided a significant symptomatic improvement in most of the patients. Moreover, the annual exacerbation rate was lower in the patients treated with surgery than those receiving medical treatment only. Taken together, the patients operated for bronchiectasis had lower anxiety and depression with a significant improvement in symptoms and lower annual exacerbation rate.

Over the years, with the advances in the field of immunization and medical treatment, the incidence of bronchiectasis has gradually decreased. ${ }^{[4]}$ However, there are still patients with bronchiectasis, who are either symptomatic or identified incidentally on chest computed tomography (CT). The first treatment option in bronchiectasis is the medical treatment. The main goal of the medical treatment in bronchiectasis is prevention and treatment of episodes, improvement of respiratory functions and quality of life, and prevention of progression and complications. With medical treatment, symptoms, exacerbations, and hospitalizations can be controlled to a large extent; however, in some cases it may be futile and surgery may become mandatory. ${ }^{[5]}$ Surgical treatment should be considered, when medical treatment is inadequate or in cases with severe hemoptysis or complications such as abscess or empyema. It can be performed with an acceptable morbidity and mortality rate. The results of surgical treatment are quite satisfactory in selected cases, particularly if anatomic resection is 
performed where healthy tissue is preserved as much as possible.

In patients with localized bronchiectasis, the main indications for surgery are frequent exacerbations, hemoptysis, and intense sputum production unresponsive to medical treatment. Other than the respiratory symptoms, psychiatric disorders such as anxiety and depression is common in patients with bronchiectasis. ${ }^{[6]}$ Olveira et al. ${ }^{[7]}$ found in their cross-sectional study that $20 \%$ of the patients had high depression scores and even anxiety was more frequent with the prevalence of $38 \%$. Similarly, in another study, anxiety and depression were common among Chinese patients with bronchiectasis and $39.9 \%$ of the patients had anxiety, while $30.1 \%$ had depression. ${ }^{[8]}$ Our study results are also consistent with previous studies reporting a higher prevalence of depression and anxiety in bronchiectasis than the estimated prevalence in healthy individuals.

In addition to the high prevalence of anxiety and depression in bronchiectasis, some respiratory symptoms have been shown to increase the risk of anxiety and depression. Anxiety/depression and respiratory symptoms show an increasing effect over each other in a vicious circle. While the symptoms such as hemoptysis, frequent exacerbation, and intensive sputum production are considered in the surgical indication, anxiety/depression, associated with these symptoms, has always been ignored by the surgeon. While one end of this vicious circle is considered a surgical indication, it is surprising and curious to ignore the other end. In the current study, we attempted to underline this point by demonstrating that both HADS anxiety and depression scores were significantly higher in the medical group, compared to the patients treated surgically $(\mathrm{p}<0.001)$. To the best of our knowledge, this is the first study to compare the emotional state of patients treated surgically and treated medically, despite being eligible for the operation. Based on these findings, we can speculate that surgical treatment reduces anxiety and depression in bronchiectasis and suggest that the emotional states of the patients should be taken into consideration while determining the indications for the surgical treatment of bronchiectasis.

In previous studies, complete recovery rates of symptoms after surgical treatment of bronchiectasis were reported as $82.1 \%$ in children and $88.7 \%$ in adults. ${ }^{[9]}$ In this study, the rate of disappearance of symptoms, suggestive of complete recovery, was found to be $72.2 \%$, consistent with the literature. The most important factor affecting the complete disappearance of symptoms after surgical treatment is that whether the resection is anatomic or not. ${ }^{[10]}$ In our study, the most common surgical procedure was lobectomy with a rate of $81.4 \%$. In patients with bronchiectasis, it is necessary to increase the anatomical resection rate to increase the recovery rates. Furthermore, both the annual exacerbation and hospitalization in the surgical group was lower than in the medical group in our study; however, the patients in surgical group still had exacerbations after the operation. This may be due to the inability to eradicate the microorganisms that are colonized in the airways. Nevertheless, the data regarding microorganism colonization are still limited. Therefore, further studies evaluating the effect of operation on bacterial colonization are required.

There are some limitations to this study. First, since our study is retrospective, the initial symptom severity of the patients was unable to be evaluated and, thus, the relationship between symptom severity and HADS was unable to be analyzed. Also, as the number of pneumonectomy cases is relatively low, HAD scores of lobectomy/pneumonectomy patients could not be compared, and the effect of pneumonectomy and lobectomy on the anxiety and depression status of the patients could not be evaluated separately. Second, the factors other than bronchiectasis that can be the reason for anxiety and depression were not examined. To illustrate, the most common and well-defined factors such as socioeconomic condition and marital status were unable to be evaluated. Third, the surgical group had no preoperative HAD scores and, therefore, pre- and postoperative HADS scores of the surgical group could not be compared. Thus, elucidating the effect of the operation on the HAD score remained limited. Finally, there is no anxiety and depression questionnaire specific to bronchiectasis. The HADS is widely used to assess depressive symptoms. However, it is not equivalent to the diagnosis of major depressive disorder.

In conclusion, our study showed that the patients with bronchiectasis treated medically rather than surgically were more anxious and depressive. This finding can be interpreted as an evidence that the benefits of surgical treatment in patients with bronchiectasis are beyond improving symptoms and decreasing the frequency of exacerbations and hospitalizations. Surgical treatment also reduces anxiety and depression and, thus, improves the quality of life. Based on these findings, while making a surgical decision, surgeons should consider anxiety/depression of the patient, the conditions at the other end of the vicious circle. 


\section{Declaration of conflicting interests}

The authors declared no conflicts of interest with respect to the authorship and/or publication of this article.

\section{Funding}

The authors received no financial support for the research and/or authorship of this article.

\section{REFERENCES}

1. King PT. The pathophysiology of bronchiectasis. Int J Chron Obstruct Pulmon Dis 2009;4:411-9.

2. O'Leary CJ, Wilson CB, Hansell DM, Cole PJ, Wilson R, Jones PW. Relationship between psychological well-being and lung health status in patients with bronchiectasis. Respir Med 2002;96:686-92.

3. Aydemir Ö, Güvenir T, Küey S, Kültür S. Turkish version validation of hospital anxiety and depression scale. Turkish $\mathbf{J}$ Psychiatr 1997;8:280-7.

4. Giovannetti R, Alifano M, Stefani A, Legras A, Grigoroiu M, Collet JY, et al. Surgical treatment of bronchiectasis: Early and long-term results. Interact Cardiovasc Thorac Surg 2008;7:609-12.
5. Vendrell M, de Gracia J, Olveira C, Martinez-Garcia MA, Girón R, Máiz L, et al. Diagnosis and treatment of bronchiectasis. Spanish Society of Pneumology and Thoracic Surgery. Arch Bronconeumol 2008;44:629-40.

6. Girón Moreno RM, Fernandes Vasconcelos G, Cisneros C, Gómez-Punter RM, Segrelles Calvo G, Ancochea J. Presence of anxiety and depression in patients with bronchiectasis unrelated to cystic fibrosis. Arch Bronconeumol 2013;49:415-20.

7. Olveira C, Olveira G, Gaspar I, Dorado A, Cruz I, Soriguer $\mathrm{F}$, et al. Depression and anxiety symptoms in bronchiectasis: Associations with health-related quality of life. Qual Life Res 2013;22:597-605.

8. Gao YH, Guan WJ, Zhu YN, Chen RC, Zhang GJ. Anxiety and depression in adult outpatients with bronchiectasis: Associations with disease severity and health-related quality of life. Clin Respir J 2018;12:1485-94.

9. Ulutaş H, Çelik MR, Kuzucu A. The role of current surgical therapy for pediatric/adolescent and adult patients with bronchiectasis. Turk Gogus Kalp Dama 2017;25:412-8.

10. Dadaş E, Tanju S, Kilıçgün A, Toker A, Dilege Ş. Bronşektazide cerrahi tedavi: Klinik özellikler ve uzun dönem sonuçlar. Turk Gogus Kalp Dama 2014;22:583-8. 